\title{
Densely Granulated Non-Functioning Corticotroph Adenoma
}

National Cancer Institute

\section{Source}

National Cancer Institute. Densely Granulated Non-Functioning Corticotroph Adenoma.

NCl Thesaurus. Code C154431.

A densely granulated corticotroph adenoma not associated with a hormonal syndrome. 